\title{
TÖNNIES' CONCEPT OF PUBLIC OPINION AND ITS UTILITY FOR THE ACADEMIC FIELD ARNOLD
}

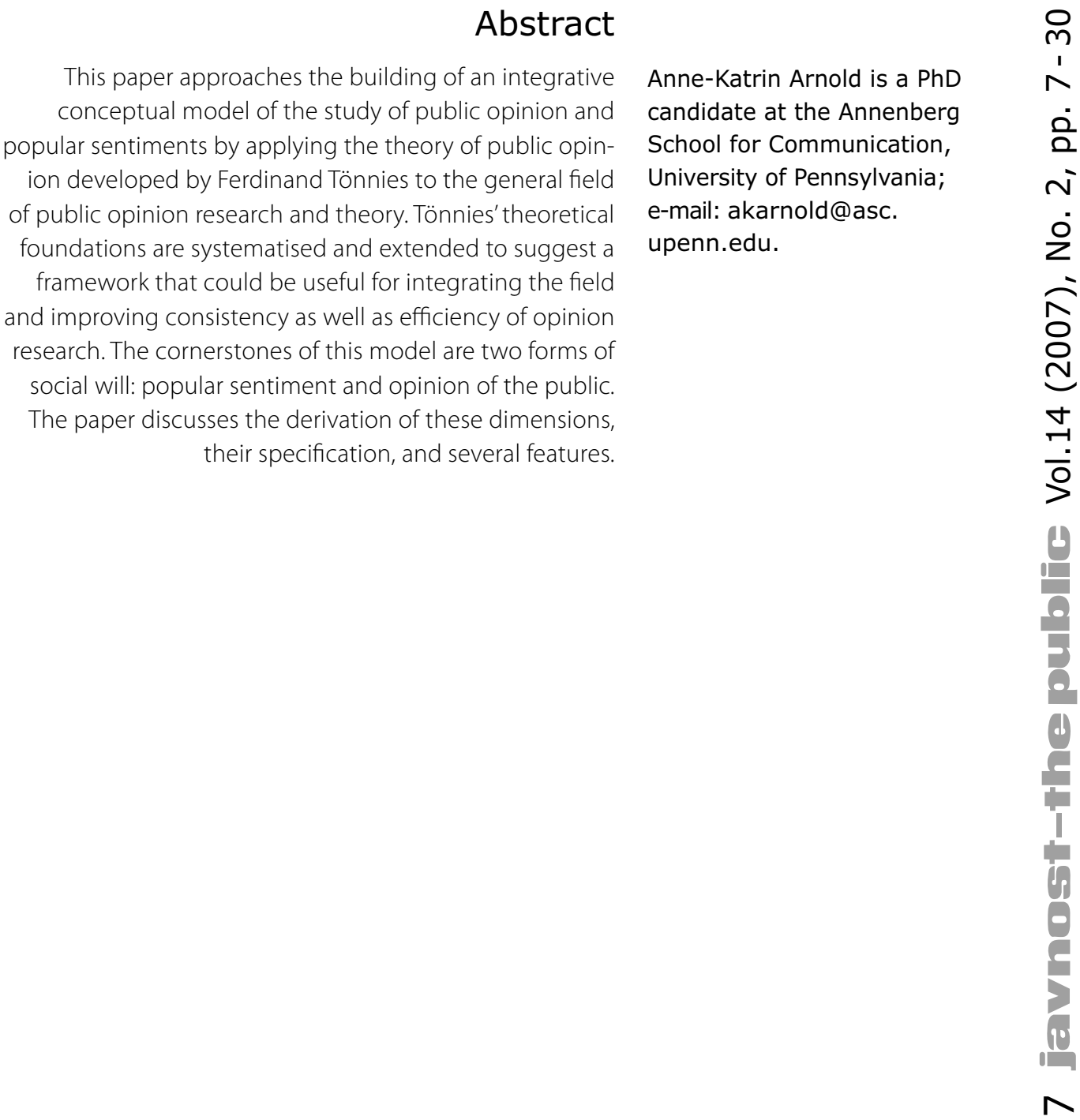




\section{Introduction: A Call for Order}

One of the main critiques about public opinion polling is that polls just do not measure public opinion. This point refers to the constant conceptual struggle within public opinion theory and research about actually defining the crucial terms as well as positioning them within a societal context. Scholarship on public opinion seems to be utterly divided on the grounds of believes: Some side with Habermas and his normative model of rational discourse, some side with Dewey or Lippmann and their more pragmatic approaches that are open to empirical operationalisation, some even see public opinion as mere aggregate of individual expression, just as Childs and Allport do.

According to Blumer's (1948) critique of public opinion polling, pollsters often do not have any kind of theoretical understanding of their research object - while Newcomb (1948) argues that they have, but that it is more empirical and closer to the reality of the population than normative approaches. This clash of concepts is typical for the field. All seem to agree that the discussion is about definitions: Is the public a theoretical ideal type of enlightened and informed citizens, or is simply everyone somehow a member of some public somewhere? Often debates close with the recognition of incompatibility without further attempts at working towards some basic consensus.

In this paper we will argue that different understandings (normative and empirical) of public opinion are not necessarily mutually exclusive, but can be integrated into a broader classification of the public and public opinion. Tönnies' typology of opinion in terms of, in Splichal's (1999) words, published opinion, public opinion, and opinion of the public is a reasonable starting point for this endeavor because it actually encompasses the supposed antagonisms of normative and theoretical theories of public opinion and more empirical approaches.

Although comprehensive and consistent, Tönnies' typology on its own is not sufficient to attempt to sketch the area of what is meant to be public opinion research and theory. For instance and not surprisingly, his classification does not account for the practice of public opinion polling (Splichal 1999, 111) that became a powerful influence in the field only after Tönnies published his writings. Therefore, we will try to extend his typology by drawing from other theories such as those provided by Tarde, Le Bon, Mills, Park, and Cooley as well as discussing the position of opinion polling and its premises in relation to those theories.

This paper is merely an attempt to illustrate that it is redundant to insist on finding one "right" definition when it is possible to trace a significant number of approaches back to a common typology of public opinion and the public. Rather than persisting in the rightness of one's own approach, it would be more beneficial for progress in opinion research to simply clarify one's position and identify with one type within a larger framework, but not in opposition to other approaches. This follows the appeal by Price (1992) that the high probability of there not being the one acceptable definition of public opinion does not mean that the concept is meaningless. Rather, to understand it public opinion scholars must look at different uses and different problems it has been applied to.

There are several things this paper cannot and does not claim to do: We will not be able to discuss all relevant or even all crucial texts on public opinion and associated concepts as they relate to the attempted classification. This paper can- 
not be more than a first approach to organise theories and understandings of the public and public opinion. Furthermore, we will have to focus on the conceptual essence of approaches to public opinion and the public. This will entail a neglect of political functions of public opinion, opinion formation processes, the relationship between public opinion and the press. Undoubtedly, these aspects are central to public opinion theory, but discussing them in this specific paper would prove an impossible task. For the same reason, the scope of works that can be included in this paper will have to remain relatively narrow.

The starting point for this paper is Ferdinand Tönnies' systematisation of public opinion. To illustrate conceptual similarities as well as amendments we will subsequently draw on conceptualisations and theoretic orientations that appeared after the publication of Tönnies' Critique of Public Opinion in 1922. The last part of the paper is dedicated to terminological clarifications and the concluding summary of conceptualisations on the grounds of Tönnies' theoretical model.

\section{The Framework: Ferdinand Tönnies on Public Opinion}

\section{Principles of Tönnies' Social Theory}

More influential than his writings on public opinion are Tönnies' contributions to the analysis of social cohesions in the forms of Gemeinschaft (community) and Gesellschaft (society) (1887/1912). The distinction between these forms is essential to the understanding of his public opinion theory for several reasons. First, public opinion exists only in society and has its equivalent in the religion of community. Therefore, there is no public opinion in community types of social organisations. Furthermore, one of Tönnies' chief achievements is the conceptual coherence of his general sociological theory (Palmer 1938). The writings that followed the publication of Gemeinschaft und Gesellschaft build on this conceptualisation and adhere to its inner logic, both expanding its scope and validity as well as refining its premises (Splichal 1999). As his critique of public opinion is grounded in his theory of social cohesion and social will, it is necessary to exemplify the latter.

Tönnies educes all social phenomena from the constructing forces of human will. The distinction between Gemeinschaft and Gesellschaft refers to the opposition between two normal concepts of will, Wesenswille (essential, organic, or natural will) and Kürwille (arbitrary, reflexive, or rational will). ${ }^{1}$ Tönnies $(1971,6)$ defines the former as "will inasmuch as it contains thinking," the latter as "thinking inasmuch as it includes will." These ideal types of social will distinguish between community and society. Community is an informally organised cohesion of people that is based on a mutual quest for communal objectives (organic will); society refers to a social organisation that is shaped by institutionalised structures and relationships, with individual members coming together to reach individual goals through the means of the whole group (reflexive will). Within these, Tönnies differentiates between elementary forms of (organic or reflexive) will referring to individual private decisions made for the group; and complex forms of will that are articulated by the whole collective, but founded in individual objectives (Splichal \& Hardt 2000). 
Table 1: Tönnies' Forms of Social Will as Ideal Types of Social Organisation

\begin{tabular}{|c|c|c|c|c|c|c|}
\hline Social cohesion: & \multicolumn{3}{|c|}{ A. Community } & \multicolumn{3}{|c|}{ B. Society } \\
\hline Social will: & \multicolumn{3}{|c|}{ organic will } & \multicolumn{3}{|c|}{ reflexive will } \\
\hline Life sphere: & $\begin{array}{l}\text { working } \\
\text { together }\end{array}$ & $\begin{array}{l}\text { living } \\
\text { together }\end{array}$ & $\begin{array}{l}\text { being } \\
\text { together }\end{array}$ & economic & political & moral \\
\hline $\begin{array}{l}\text { Elementary } \\
\text { social will: }\end{array}$ & $\begin{array}{l}\text { under- } \\
\text { standing }\end{array}$ & tradition & faith & contract & norm & doctrine \\
\hline Life sphere: & order & law & moral & order & law & moral \\
\hline $\begin{array}{l}\text { Collective } \\
\text { social will: }\end{array}$ & concord & custom & religion & convention & legislation & $\begin{array}{l}\text { Public } \\
\text { Opinion }\end{array}$ \\
\hline
\end{tabular}

(Based on Splichal \& Hardt 2000, 177; Splichal 1999, 105-107; Tönnies 1971; Tönnies 1922)

Tönnies (1887/1912) argues that the historical development of the forms of social will has been from A to B: While the forms under A. (community) are original and essential, the forms under B. (society) are derived and made essential. B-forms develop out of A-forms and in the course of time B-forms turn into the leading social will: Convention becomes more important than concord, legislation more important than custom, and Public Opinion more important than religion.

\section{Published Opinion, Public Opinion, and Opinion of the Public}

As illustrated in Table 1, Public Opinion is related to faith and religion in community and to doctrine as elementary form of social will in society. Religion on a community level corresponds with Public Opinion on a societal level - according to Splichal $(1999,109)$, the "opinion of the public is a rationalised form of religion," and both refer to morality. Unlike Kant, Tönnies connects Public Opinion to reason and sees religion as inferior. Kant (1795/1939) identifies three mental stages of "holding for true" that are determined by the subjective and objective validity of judgment (Splichal 2000). Knowing is the primary form, being both subjectively (for myself) and objectively (for others) sufficient. Believing is subjectively sufficient and objectively insufficient, and opining is both subjectively and objectively insufficient. In tracing the etymology of the terms, Tönnies $(1922,13)$ argues that belief is a matter of the heart because it is based on trust, whereas opinion is a matter of the head because it requires thinking. Therefore, the latter has more validity.

Tönnies' Critique of Public Opinion spans 575 pages in the German original (1922). Although his theory is "one of the most significant classical social-theoretical contributions to the field" (Splichal 1999, 99), it will not be possible to discuss his entire account. Accordingly, we will only refer to conceptual principles of his theory as they regard public opinion and the public. More or less comprehensive introductions going beyond theoretical premises can be found in Splichal (1999), Splichal and Hardt (2000), Gollin and Gollin (1973), Keane (1982), and Palmer (1938).

The Public. In his Critique, Tönnies (1922) does not conceptualise the term "public," but he provides a description of what he calls "The Audience," or the "large audience," which apparently is his denomination for "the public." He describes 
it as an unlimited number of people that, despite their numerous dissimilarities, might think and judge among the same lines. This audience does not and cannot assemble but lives and acts in various circles. The audience can make itself be heard - although only in "subdued grumbling or hoarse cries, in derisive laughter or in mirthless lamentation and ... in signs of approval or disapproval, amazement and suspense" (p. 84, own translation). The audience only exists with regard to specific issues or events, and in such cases it consists of all people that are able and willing to participate, absorb, and judge. To do so, the members of the audience/ public must have a certain degree of intelligence and education because in order to judge they have to be informed. In his days, Tönnies goes on, the audience almost exclusively consists of newspaper readers because the press is the primary means to access information. "In every respect the audience, if not thought of as being bound to a specific place or a specific time, is an idea of indeterminable width and duration - also insofar it is signified by general or specific, particularly political 'education'" (p. 85, own translation).

Public Opinion. The conceptualisation of public opinion provided by Tönnies is significantly more comprehensive and detailed than his notion of the public, but it is also somewhat confusing. In his Kritik der öffentlichen Meinung (Critique of Public Opinion, 1922), he varies the spelling of the term by using capital letters and indefinite articles (Splichal 1999). Die Öffentliche Meinung (Public Opinion), eine öffentliche Meinung (a public opinion), and öffentliche Meinung (public opinion) stand for three different phenomena, although Tönnies does not consistently differentiate accordingly, but rather uses the nondescript öffentliche Meinung whenever he is not explicitly differentiating one from the other.

To come to terms with the confusing terminology, Splichal $(1999,111)$ suggests a systematisation of Tönnies' terminology and differentiates between "opinion of the public" (die Öffentliche Meinung/ Public Opinion), "public opinion" (eine öffentliche Meinung/ a public opinion), and "published opinion" (öffentliche Meinung/ public opinion). The first instance is the "articulated" and only "real" public opinion (Tönnies 1922) and is a purely theoretical ideal type that cannot be observed empirically (Splichal 1999). Splichal translates Tönnies understanding of opinion of the public as a "common way of thought, the corporate spirit of any group or association, in so far as its opinion formation and expression ... is built upon reasoning and knowledge, rather than on unproven impressions, beliefs, or authority" (p. 101). The scope of this phenomenon is large, it represents consensus within a nation and stems from as well as embodies values and beliefs of a society (Gollin \& Gollin 1973). "The public opinion as generalised opinion of a people or a public as a whole" is a "unified harmony of many thoughts and opinions," a "social volition" that is manifested as if it were the will of one person (Tönnies 1971, 258).

Public opinion is the agreed upon judgment of a group (class, party etc.), whereas published opinion does not form any unity and is merely public because it is expressed not in private or confidentially, but openly to any given audience (Tönnies 1922). Table 2 provides a summary of the basic properties of the different types of opinion introduced by Tönnies: 
Table 2: Opinion Types

\begin{tabular}{|c|c|c|}
\hline \multicolumn{1}{|c|}{ Published opinion } & \multicolumn{1}{|c|}{ Public opinion } & \multicolumn{1}{c|}{ Opinion of the public } \\
\hline $\begin{array}{l}\text { Individual opinion intentionally } \\
\text { expressed publicly, different } \\
\text { from private or confidential } \\
\text { opinion }\end{array}$ & $\begin{array}{l}\text { Conglomerate of published } \\
\text { opinion that is shared by many, } \\
\text { agreed upon opinion }\end{array}$ & $\begin{array}{l}\text { Formal-theoretical concept, } \\
\text { public opinion as form of so- } \\
\text { cial will, societal values, actual } \\
\text { articulation of public opinion, } \\
\text { its subject is the public }\end{array}$ \\
\hline
\end{tabular}

Degree of adoption by (agreement among) the majority

(Based on Tönnies 1922; 1971; Splichal 1999; Gollin \& Gollin 1973)

The second classification refers to "opinion of the public" and distinguishes between three aggregate states of public opinion that are determined by the degree of unity among the public (Splichal \& Hardt 2000). Palmer (1938) sees the degree of solidity of an opinion as its degree of strength: the stronger, the less open is the opinion to external influence. Reliability and strength of the opinion of the public vary between gaseous, fluid, and solid states. Solid opinion, a product of reason, refers to an immovable conviction of a nation or an even larger group of people. Tönnies (1922) names the rejection of absolutist regimes or torture as examples of solid opinion. It loses solidity when it is applied to less general concepts, to political events for instance, and is both fiercely defended by one part of the people and opposed by another at the same time. Gaseous opinion is very similar to published opinion, but is explicitly a part of opinion of the public because it depends on fluid and solid states (Splichal 1999) and is congruent with them (Splichal \& Hardt 2000). "Opinion of the day" - gaseous or ephemeral opinion - is determined by fluid and mainly by solid opinion; it is basically their application to daily specifics. Solid opinion can proceed through the stages and "evaporate" into the gaseous state (Tönnies 1922), although historically the development happens the other way round: Opinions strengthen over time and might become a principle value of a nation. The older the opinion, though, the more adamant criticism, and therewith solid opinion liquefies and eventually dissolves (Splichal 1999).

Table 3: Aggregate States of Opinion of the Public

\begin{tabular}{|c|l|l|}
\hline \multicolumn{1}{|c|}{ Gaseous (ephemeral) } & \multicolumn{1}{|c|}{ Fluid } & \multicolumn{1}{c|}{ Solid (firm) } \\
\hline $\begin{array}{l}\text { Superficial, changes rapidly, } \\
\text { biased, opinion of the day, an } \\
\text { 'impolite child,'not strictly pub- } \\
\text { lic opinion in the normative } \\
\text { sense, example: daily press }\end{array}$ & $\begin{array}{l}\text { Changes with Zeitgeist, chang- } \\
\text { es with shifting meanings of } \\
\text { what is 'good,' example: moral } \\
\text { questions }\end{array}$ & $\begin{array}{l}\text { Convictions representing a } \\
\text { whole nation or larger group, } \\
\text { agreement over general values, } \\
\text { rational, example: democratic } \\
\text { values }\end{array}$ \\
\hline
\end{tabular}

Unity of the public

(Based on Tönnies 1922; Splichal 1999; Splichal \& Hardt 2000) 
Tönnies' theory in itself is a major contribution to the field of public opinion study, not least because it displays a remarkable "coherence rarely achieved by social theorists and researchers" and his concepts constitute "a philosophy of history of remarkable sweep and power" (Palmer 1938, 594). The theory's fundamental meaning for the whole field of public opinion scholarship becomes apparent when major controversies among opinion scholars that have arisen after the publication of his work are exemplified in a historical context and then related back to his typology of different forms of opinions in the public.

\section{The Mass, the Crowd, and the Public}

Historical conceptual transformations as illustrated by, for instance, Price (1992), Splichal (1999), Osborne and Rose (1999), or Childs (1965) reveal that conceptual confusion has rather grown than decreased in the past decades, which again is an argument for attempting to conceptually systematise the field. Noelle-Neumann (1976) bemoans that by the late 1960s, the term "public opinion" had become arbitrary with every author propagating an own interpretation so that it was merely possible to state that there was no common definition.

Price (1992) presents a historical analysis of public opinion theory and research that focuses on conceptual changes in the understanding of the core terms. He identifies two major, albeit connected developments: The first refers to a shift away from viewing the public and public opinion as elitist and confined to a small group of educated and informed people toward the inclusion of the mass. Masses are not necessarily regarded as publics (although some take this stand, e.g. Key 1961, see below), but the notions were discussed and defined in contrast to or by inclusion of and therefore in the context of masses. The second shift happened both in focus and in methodology close to 1900. As Price (p. 15) explicates: "In tandem with the growth of the social sciences within the academy, 20th-century works on public opinion more clearly reflected sociological and psychological rather than political and philosophical concerns." The problem of harmonising opposing individual wills gave way to the analysis of social and behavioral aspects of public opinion. Public opinion was studied in new academic fields: social psychology, attitude and opinion research, propaganda analysis, political behavior, and mass communication research.

Basically, public opinion research followed the shift from communitarianism to individualism that is implied in Tönnies' model of community and society. This shift affected approaches to the public from

formulations of the public as a fluid and amorphous group of freely associat-
ing citizens willing to think and debate in consideration of the good of the
whole community, to highly individualist formulations equating it with the
mass of citizens freely pursuing their personal and group interests as they
wished, and by majority vote aggregating those interests to choose wise
political leaders (Price forthcoming, 8).

Chronologically, focus shifted first from the public toward crowds, and then on to masses. There are several reasons for these changes that cannot all be addressed here. Again, for the concern of this paper, conceptual changes in the definition of public and public opinion are paramount. 


\section{Crowd Psychology}

Social theory always refers to current events. Accordingly, when spontaneous crowds, demonstrations, strikes, and riots rose in the wake of industrial society, historical context and attention toward non-rational aspects of public opinion simultaneously evoked the emergence of sociological conceptions and studies in crowd psychology in the late 19th and early 20th centuries (Price 1992). Undoubtedly, the studies of Gabriel Tarde, Gustave Le Bon, and Robert Park are among the most insightful accounts of social changes underlying the appearance of crowds and their meaning for public opinion theory.

Tarde (1969) does not yet let go of the idea of the imaginary public, but exemplifies its attributes by contrasting it to the crowd. The opposition between crowds and publics illustrates the physical nature of the former and the "metaphysical" nature of the latter. While a crowd is often (though not necessarily) gathering in one locality and consists of actual individuals that are physically present, the members of the public do not know each other and have no physical contact. Basically, they are sitting in their studies reading the same newspaper article. The public is constituted by "their simultaneous conviction or passion and in their awareness of sharing at the same time an idea or a wish with a great number of other men" (p. 278).

Crowd psychologists and sociologists usually differentiate between public and crowd, but not insofar as they understand the public as being infinitely higher developed. On the contrary, both share a substantial number of attributes. For Park (1972), both collectives are similar insofar as they are mechanisms of transforming social groups into new organisations, both are not yet organised. The crowd's organisation is still less sophisticated, the crowd is the "first degree of the social aggregate" (Tarde 1969, 288).

The most common understanding of a crowd is that of a physical gathering at a given time and place. The psychological phenomenon of the crowd or the "crowd mind" as described by Le Bon (1897/1960) does not necessarily presuppose physical and simultaneous presence in one place at one time, rather "thousands of isolated individuals may acquire at certain moments, and under the influence of certain violent emotions - such, for example, as a great national event - the characteristics of a psychological crowd" (p. 3, emphasis added). Park (1972) agrees by stating that a unified emotional state is enough to create such a psychological crowd. The spatial aspect becomes dispensable as "the crowd must be viewed as simple emotional state controlling a number of individuals" (p. 20). This is also supported by Tarde (1969) when he says that "the newspaper will create an immense, abstract, and sovereign crowd, which it will name opinion" (p. 318). His understanding of the public forgoes physical and spatial aspects when imitation, the basic principle of crowd interaction, is detached from the necessity of people being in each others presence (Borch 2005). This is possible, for instance, when the mass media carry information on a person's actions, possibly on those of a celebrity.

The opposite is claimed by Carl Schmitt (1928, cited in Splichal 2000, 33-35). He understands public opinion as acclamation that is produced only when people gather in one space. Drawing from constitutional assemblies as principle of democracy, he argues that a public is constituted by the physical presence of people. Public opinion is unorganised and has no special function - as Splichal (p. 34) points out, “Schmitt's different forms of people's gathering, supposed to constitute the basis 
of the public, are forms that Park saw as typical examples of the crowd." Interestingly, the same applies to Tönnies (1922). While using the name "large audience" for what would commonly be understood as public, he also specifies his meaning of public. As Schmitt's, his definition of "public" points to core characteristics of the crowd, especially when contrasted with the audience. He describes the public as being associated with political life. Its natural habitat is urban and in the streets ("in publico," Tönnies 1922, 100) and the marketplace, or in any other location accessible by everyone. In contrast to the spatial freedom of the "large" audience, this public relies on physical gatherings.

For Blumer (1946), the public is a group of people confronted by an issue, divided over how to meet the issue, and engaged in discussion over the issue. Its basic distinction compared to the crowd is the rational factor - although emotions do play a role in the public, the process of argument and counterargument, which eventually produces public opinion, preserves rationality in the public. The crowd, on the other hand, following affective impulses, produces public sentiment. In terms of this sentiment they are emotionally unified by a process of reciprocal imitation and contagion that eventually leads to the dissolution of individual consciousness into a "crowd mind" (Le Bon 1897/1960; cf. Park 1972): A leader repeats a message to the members of a crowd that quickly lose their natural or social inhibitions because they are anonymous among a number of other people. The repeated messages - emotions or actions - spread through the crowd by contagion (Tarde would say by imitation); individuals lose self-consciousness and their minds and wills become absorbed in a collective mind. The public's main characteristic is opposition and rational discourse, but Park notes that as soon as rationality is abandoned - for instance, because the members of the public become overly excited about an issue - the public becomes a crowd.

Neither members of a crowd nor members of a public are joint by harmonised interests, but by "reflecting, fusing through their innate or acquired similarities into a simple and powerful unison" (Tarde 1969, 286). Although more effective in the public, in both cases this process eventually results in a phenomenon that is more than the sum of individual psychological processes because it is based on interaction between people.

But not only rationality differentiates public and crowd, consciousness is another factor. Individuals join a crowd unconsciously and without premeditation, whereupon emotional unity is achieved through reciprocal imitation. A public emerges on grounds of an "undefined basis of the common consciousness" where individual interests can even "develop further in a peculiar reciprocal interaction" (Park 1972, 50). Pessimistically, Park sees the public mostly at the same stage of awareness-development as the crowd - therefore, public opinion is only a naïve collective impulse that can easily be manipulated, especially by the press. "The 'opinion' formed in this manner shows a form that is logically similar to the judgment derived from unreflective perception: the opinion is formed directly and simultaneously as information is received" (p. 57). For Park, public opinion is the crucial difference between both groups: The crowd does not go beyond perception, whereas publics express themselves. The behaviour of the public is the expression of public opinion.

Tarde (1969) has an equally unambitious understanding of public opinion, which interestingly does not correspond to his definition of an imaginary public, but does 
match both Park's notion of the public and Tönnies' public opinion ${ }^{2}$ (as termed by Splichal 1999): “Opinion, as we define it, is a momentary, more or less logical cluster of judgments which, responding to current problems, is reproduced many times over in people of the same country, at the same time, in the same society" (Tarde 1969, 300). Before the advent of the press, which marked the emergence of the public, there have been public opinions without any public.

Referring back to Tönnies, crowd psychology both confirms and enriches his typology. Tarde $(1969,281)$ is adamant that the crowd is no public, indeed, "from the crowd to the public is an enormous leap." It is obvious that crowds and the formation of crowd will do not correspond to what Tönnies understands as solid opinion of the public, a crowd is not his "large audience"; the manifestation of the crowd will is not a "common way of thought" (Splichal 1999, 101) and does not represent consensus within a nation (Gollin \& Gollin 1973).

In order to integrate crowds into Tönnies' typology, we have to start our line of argument at the basic distinction between community and society. Crowds, though less rational and less organised than a public, are phenomena of society, not community. Empirically, Tönnies (1922) describes the reflexive will of societies as being about the particular, whereas the organic will of communities is about the general. Crowd gatherings are not about understanding, concord, tradition, custom, religion or faith in general (as organic will would be), they are most obviously related to doctrine and public opinion as forms of reflexive will in societies.

The main problem with including crowds into Tönnies' systematisation of public opinion is his own ambiguous terminology. He uses the term Menschenmenge (crowd) in the context of ephemeral - gaseous - opinion of the public, but describes it just as he described published opinion earlier, as "impolite child," superficial, changeable, prejudiced etc. (Tönnies 1922, 245-253). The difference is in the influence of fluid and solid opinion of the public: Both have no necessary link to published and public opinion, but are always inherent in the gaseous state.

In terms of the crowd and its relation to public opinion, it is difficult to designate it either to the realm of opinion of the public, albeit in an ephemeral state, or to published and public opinion - the characteristics of the crowd would fit all three. As long as crowds rally for reasons of social justice, freedom etc. they might well be part of the opinion of the public, but as a general phenomenon, crowds can rally for anything. Le Bon (1897/1960) provides a leverage to solve this problem by identifying two classes of ideas of crowds: In one class are "the fundamental ideas, to which the environment, the laws of heredity and public opinion give a very great stability; such as the religious beliefs of the past and the social and democratic ideas of to-day" (p. 48). Clearly, crowds driven by such ideas eventually form ephemeral opinion of the public. However, the second class of ideas is made up of "accidental and passing ideas created by the influences of the moment: infatuation for an individual or a doctrine, for instance" (p. 48). Nevertheless, eventually "it is only hereditary ideas that have sufficient influence over the isolated individual to become motives of conduct" (p. 50).

A second key to including crowds into Tönnies' systematisation comes from Tarde's $(1969,290-294)$ distinction between expectant, attentive, demonstrating, and active crowds. The first two can be roughly summarised as passive crowds - spectators at the theatre or the audience of a speaker - that are usually physically 
present at one location. The latter two are more or less active. Here we apply Le Bon's $(1897 / 1960,48)$ assumptions that crowds' motivation to take action rests on hereditary ideas. For the more passive forms it is conceivable that they evolve out of "accidental and passing ideas." Admitting that there might be empirical overlaps between active crowds as ideologically motivated formations and passive crowds as more or less chance gatherings, we attribute the former to Tönnies' ephemeral opinion of the public, and the latter to public opinion. As Tönnies (1922) points out himself, only opinion of the public in its three aggregate states is actual public opinion, therefore, passive crowds are not part of the public. Later we will present a discussion of vocabulary that will distinguish between both terms.

Having attributed active crowds to ephemeral opinion of the public, it remains to be clarified if crowds should be defined as published opinion rather than public opinion. As exemplified earlier, published opinion, according to Splichal $(1999,111)$, "represents an individual's publicly expressed opinion," different from private or intimate opinion, and directed toward a general audience. Tönnies (1922, 131, own translation) describes it as "unarticulated" but nevertheless publicly expressed and referring to public issues. Public opinion is an agglomerate of published opinion that is shared by many, "a majority of an open or closed circle, particularly if it clearly expresses support or opposition" (p. 131; cf. Tönnies 1971). It is a transition stage between published opinion and opinion of the public. Thus far, the crowd phenomenon can be both, but might be closer to public opinion ${ }^{3}$ : The formation of the will of the crowd is dependent on the initial expression of the will of one or few individuals, but eventually there is consensus among a majority of a closed circle about a common objective and standpoint. When published opinion

becomes an opinion and a judgment of the many ... - if its weight is judged by the weight of a majority of a meeting - if it is a judgment of a unity, a circle, or a unity that is united into a community or society, then we could call it public opinion (Tönnies 1922, translated in Splichal 1999, 114).

The press created a trend that points to the next social phenomenon connected to the study of public opinion. According to Tarde (1969), the press caused a considerable increase in the importance of quantities, of numbers. While in primary social groups (marked by personal contact between group members) the quality of individual opinions matters, in secondary groups of mass society (without personal contact among group members) quantity wins over quality (Blumer 1966/2000). This in combination with other developments in society, economy, and the sciences, caused a significant transformation for the study of public opinion. After a brief excursion into crowd psychology, public opinion students of the early 20th century moved on toward an understanding of public opinion as aggregate of individual opinions of persons that most often are in no other way connected to each other than by being asked the same questions by a polling agency.

\section{Mass Society}

Beniger quotes the opening sentences of the founding editors of the academic journal Public Opinion Quarterly:

A new situation has arisen throughout the world, created by the spread of literacy among the people and the miraculous improvement of the means of communication. Always the opinions of relatively small publics have been 
a prime force in political life, but now, for the first time in history, we are confronted nearly everywhere by mass opinion as the final determinant of political, and economic, action (Beniger 1987, S46-S47).

Taken literally, this statement would imply that the shift from elite publics to masses is not due to a more democratic paradigm in the study of public opinion, or the growth of quantitative survey methods, but is a necessary transformation that comes with contemporary social development - masses simply penetrate the public and thereby become members. In this sense, the public would still have to be regarded as public in the traditional sense, only with a new composition of membership. "Mass" would then be a variation of "public," and therefore mass opinion would be a variation of public opinion (as suggested by Key 1961).

Unfortunately, things are more complex. Since the 1930s critical scholars have argued with opinion researchers about new definitions of the public and public opinion, and about new approaches to their analyses. This dispute has not much softened in tone and volume until the present day, although conceptual successors have appeared on both the critical and the empirical side in more recent years.

The classical discursive model of public opinion had been discarded by early empirical opinion researchers in the first half of the 20th century because it was largely inaccessible for empirical research (Price 1992). With the rise of survey research and public opinion polling, the complex composition of publics, as described by democratic theorists in the 19th century, was supplanted by the notion of "one man, one vote," consistent with populist democratic ideals (Splichal 2000). Although scholars are less at one about conceptualisations than ever, there is unity as to the origin of the shift away from public opinion as supra-individual collective phenomenon to a more individualistic perspective. Methodological advancement in the social sciences, particularly in psychology, opened new possibilities to access large parts of the electorate or the entire population and assess their opinions on all kinds of issues in close proximity to certain events or governmental actions.

During the Second World War, psychologists improved their research instruments by extensively applying them to the screening of soldiers (Childs 1965). This caused increased attention to the quantitative measurement of attitudes in the field of public opinion research. The key innovation of probabilistic sampling allowed for representing large groups by relatively few respondents (Osborne \& Rose 1999; Price 1992). This made the "weird conceptions" of "public opinion ... as a mysterious vapor that emanated from the undifferentiated citizenry" and "enveloped the apparatus of government to bring it into conformity with the public will" superfluous (Key 1961, 536). Advocates of this approach often quote Bryce's ideal of democracy:

the will of majority of the citizens were to become ascertainable at all times, and without the need of its passing through a body of representatives, possibly even without the need of voting machinery at all. In such a state of things the sway of public opinion would have become more complete, because more continuous, than it is in those European countries which ... look chiefly to parliaments as exponents of national sentiment. The authority would seem to remain all the while in the mass of the citizens (Bryce 1888, cited in Graves 1939, 103). 
Childs (1965) lists a number of definitions that illustrate that by the mid 1960s the main differentiation in public opinion research was between a specialised public with limited membership, and a "mass public" including every person, or at least every person eligible to vote. Accordingly, in these definitions public opinion was determined as opinion expressed by concerned and informed people after discussion on the one hand, and the aggregate of individual attitudes on the other. The latter group of definitions typically refer to some part of opinion research methodology, a rather drastic one coming from Beyle (1931, cited in Childs 1965, 15): "Public opinion is not the name of a something, but a classification of a number of somethings, which in statistical arrangement in a frequency distribution presents modes or frequencies that command attention and interest." Childs adapts this perspective as he subsumes under public opinion any collection "of individual opinions wherever they may be found" (p. 13). Childs frequently uses the term "mass opinions" as equivalent to public opinion, taking large publics to be "mass publics" (p. 45).

Converse (1987) is among the advocates of public opinion as aggregate of individual opinions. He credits the polling industry with homogenising and stabilising the definition of public opinion predominantly applied today. Disregarding writings by critical scholars such as Habermas, Converse states that the "one person, one vote" concept "has now become the consensual understanding the world around as to a baseline definition of public opinion" (p. S14). This approach entails a loss in conceptual exactitude as seemingly everyone is a member of one public or another, and everything a person thinks or says or implies towards any issue, object, or person is public opinion. Key (1961) acquits researchers of the need for any kind of specification and states that in order to conduct political analysis it is not necessary to theorise normatively about

an eerie entity called "public opinion." One need not seek to find "the" public embodied in some kind of amorphous social structure that goes through recurring patterns of action as its reaches a decision. "Public opinion" in this discussion may simply be taken to mean those opinions held by private persons which governments find it prudent to heed (Key 1961, 14).

It can be shared by many or few, be weak or strong, be the result of deliberation or less firmly founded. Public opinion can, but need not concern policy issues; it might refer to "many objects other than issues" (Key 1961, 16, emphasis added). Furthermore, it is redundant to define or describe "the public" because the public is different for each issue. For Childs $(1939,331)$ the term "public opinion" is meaningless unless related to a specific public, specific opinions, or specific subjects. As public opinion is merely a verbal expression by an individual, not by a group, it therefore is nothing more than "any collection of individual opinions." Aspects such as the degree of agreement or uniformity, opinion quality, composition of a specific group, and typical issues are to be studied and not to be defined.

So far, Tönnies' opinion of the public seems to have been excluded from these empirical approaches to public opinion. Aggregate individual opinion corresponds not with his public opinion, but to some degree with his published opinion - which Tönnies does not regard as being actual or real public opinion. The exclusion of the theoretical opinion of the public and even of the more readily applicable public 
opinion from approaches to the study of public opinion has been challenged on two accounts.

(1) Blumer, Ginsberg, and Mills are among the most prominent representatives of a social critique. The "universe of discourse" has been circumscribed by the media, therefore there is little public discussion, and what remains is not sovereign (Blumer 1946). The democratic ideal of public opinion arising from rational and equal debate is not in accordance with present day reality, the public is transformed into a nondescript, voiceless, and helpless mass (Mills 1956). This major trend of modern society is, for Mills, a main reason for the breakdown of the liberal optimism of the 19th century, by the middle of which individualism had begun to replace collective forms of social cohesion. Ginsberg $(1986,69)$ traces these changes back to government institutions that have created an environment in which they can easily manipulate the opinion of the citizenry in order to perpetuate power structures. In his interpretation, polling is an important instrument for subduing the masses: Whereas prior to polling research public opinion could only be inferred from political action, polling "transformed public opinion from a behavioural to an attitudinal phenomenon" by not demanding any kind of action on behalf of the opinion holder. All taken together obstruct democracy insofar as institutions of political (mass) participation "may become merely the means through which citizens will occasionally wave the ends of their chains" (p. 31).

(2) Specific methodological implications exemplify the effect of mass society on public opinion research. Blumer (1946) sees the public as being gradually overtaken by the mass, public and mass intermingle and are increasingly hard to differentiate - which is, obviously, an obstacle for research regarding the public. Mills (1956) goes one step further stating that the mass has actually supplanted the public because these days more people receive opinions (via mass communication) than express them.

The utilisation of psychological scales to measure public opinion has caused confusion between opinions and attitudes. Price (1992, 46-47) specifies opinions as situational and therefore fluctuating "observable, verbal responses to an issue or question" that presuppose some cognitive effort. Attitudes, on the other hand, have most commonly been conceptualised as general, durable "covert, psychological predisposition or tendency" that is charged affectively (p. 47). Particularly the psychologisation of opinions has distinct implications for extending Tönnies' public opinion typology to account for recent trends in public opinion research. Before discussing this further, though, it is helpful to demonstrate explicit changes in terms of conceptualising the public. Price (1992, 33-43) systematises notions and operationalisations of the public in a way that corresponds, he says, to the continuum from mass to public that is recognisable in the field of public opinion study today. He distinguishes between the general public, the voting public, the attentive public, and issue publics. To some extent, this reminds of Tarde's (1969, 290-294) classification of crowds as discussed above: The general, voting, and attentive publics Price describes correspond to Tarde's expectant and attentive crowds and therefore are, strictly speaking, not publics. The active and issue publics, on the other hand, relate to demonstrating and active crowds, which we have labelled true publics earlier in this paper. Table 4 provides a brief outline of this systematic. 


\begin{tabular}{|c|c|c|}
\hline \multirow[t]{5}{*}{ Mass } & \multirow{3}{*}{ 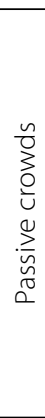 } & $\begin{array}{l}\text { General public: } \\
\text { entire given population, underlying most research practices today, unorganised, } \\
\text { disconnected, individual responses formed outside the arena of public debate } \\
\text { - mass opinions. }\end{array}$ \\
\hline & & $\begin{array}{l}\text { Voting public: } \\
\text { electorate, one of the most common operationalisations of the public, elections } \\
\text { considered the most visible manifestation of public opinion. }\end{array}$ \\
\hline & & $\begin{array}{l}\text { Attentive public: } \\
\text { individuals that are informed and interested in terms of public issues, audience for } \\
\text { political actors handling the issue, identified in surveys through political interest, } \\
\text { political conversation, news consumption. }\end{array}$ \\
\hline & \multirow{2}{*}{ 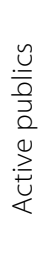 } & $\begin{array}{l}\text { Active public: } \\
\text { elites, both formal and informal political participation, recruit supporters for their } \\
\text { position in the realm of the attentive public. }\end{array}$ \\
\hline & & $\begin{array}{l}\text { Issue publics: } \\
\text { movements in composition and size of publics according to issues, consists of } \\
\text { attentive and active members, well informed members with specific long-term } \\
\text { issue interests, e.g. interest groups, advocacy organisations. }\end{array}$ \\
\hline
\end{tabular}

(Based on Price 1992, 33-43; Tarde 1969, 290-294)

It is important to note, as Price does, that each of these collectives can play a significant role in opinion formation. "It is in this sense that the search for the public is likely to be in vain. ... It is in the interaction among these groups - as they form and change over time - that answers are likely to be found concerning the collective formation and impact of public opinion" (Price 1992, 43).

Again referring to Tönnies, no discussion is needed about whether or not to include masses in any form of the public - the differences between the two have been made obvious. Furthermore, Tönnies (1922, 130, own translation) defines his public opinion as conglomerate of published opinion that is agreed upon: "Public opinion is the essentially unanimous or at least appearing to be unanimous opinion of any circle, the common judgment of a collectivity, especially if and inasmuch it approves or disapproves." Masses as such can not form this kind of public opinion. In order to agree upon something, there has to be some form of communication, but, according to Blumer (1946), members of a mass are neither bound by shared emotion nor discussion, their only link is a common focus of interest or rather attention, which is insufficient to agree upon any matter.

Published opinion in Tönnies' use of the word is considerably closer to the characteristics of masses, but still does not cover all peculiarities. Understood as entirety of the manifold contradictory opinions that are uttered publicly (Tönnies 1922), published opinion is obviously very similar to the content of the media that cater to the masses. It is not, however, a product of the members of the masses themselves. The subject of published opinion is not the mass, but rather the media industry. Even when considering opinion polling, the utterances of every individual do not, eventually, stand for such public expression, as polling "does not fulfill the conditions of intentionality and public representation" (Splichal 1999, 111). When understanding the expression of the will of the masses as voting, and the manifes- 
tation of its will as majority, the mass phenomenon needs to be treated as a new category that extends Tönnies' typology (which will eventually be incorporated in Table 5).

To this day, the dispute between mass approaches to public opinion and more traditional, discursive models has persisted for over 70 years. In the meantime, critical schools have contributed revisions of the discursive ideal that account for new communication technologies and continuously changing social surroundings. As the conceptual essence of these models is related to the public opinion concept of democratic theory and therefore both to Tönnies' opinion of the public and public opinion, they will be mentioned briefly.

\section{After the Masses - Back to the Public Sphere?}

Theories in the critical tradition dating from the second half of the 20th century mainly refer to the public and the public sphere, less to actual public opinion. In its functions as keeper of democracy and moral conduct, the public had been at the center of a wide variety of theories in several eras of public opinion study. Previously, empirical concepts of the 20th century paid some attention to the public - obviously because the observer needs to find the observed before he can make observations. However, less quantitative concepts initiate discussion on structures of the public and the public sphere. Habermas' analysis of the Structural Transformation of the Public Sphere (1962/1991) is the most notable contribution in this regard. He examines the organisation of the public sphere as it developed from the rise and breakdown of the bourgeois public to today's public sphere that is pre-structured and dominated by the increasingly powerful mass media. This domination transforms the traditional bourgeois public sphere into an arena for battle over the power to change and control communication flows that in turn affect behavior (Habermas 1992). His theory is ultimately normative, although he combines it with empirical elements of a historical analysis. He suggests deliberative democracy as model for a normative, discourse centered democracy. This idea is taken up by Thompson (1995) who calls for equal access to collective decision-making processes. Due to the ubiquity of mass media, deliberative democracy would be a mediated democracy; deliberations would therefore depend on media institutions.

The deliberative principle has also entered empirical public opinion research. Fishkin, Luskin, and Jowell $(2000,665)$ describe an elaborate process of providing participants of a study with information about a given issue and also with opportunities to discuss these with others. This is supposed to model the actual opinion formation process as it would be, had the respondent had interest and information on the issue outside the study. The authors summarise: "Deliberative polling gives insights into how electors can produce better-reasoned preferences grounded in evidence about the complexities of controversial public issues ... and how these opinions change after due deliberation."

These conceptualisations allow for more insight into the actual specifics of public sphere and public, and therefore exemplify Tönnies' typology. So far, the largest challenge to this model has been posed by definitions of public opinion as the sum of individual opinions as well as publics as any given conglomerate of individuals. Before being included in the model, these concepts have to be discussed with regard to terminology in an attempt to detangle confusion arising from the application of the same vocabulary to different and even mutually exclusive concepts. 


\section{Tönnies Continued: Conceptual Principles in the Study of Public Opinion}

\section{Terminological Aspects}

The main problem arising from discussing mass society in relation to public opinion is a blurring of lines between the public and the private, accompanied by growing arbitrariness in terminology. Empirical opinion researchers often equate mass and public, refer to mass opinion as a category of public opinion, and accordingly treat masses (such as media audiences or survey respondents) as if they were publics. Therefore, the first distinction has to be drawn between the public and the private. Even though the private sphere might affect the public sphere (Habermas 1992), a meaningful definition of public opinion can only be established if all private elements are excluded. Dewey confines all consequences of actions to the private sphere when these have an effect only on those who are engaged in the action. On the contrary, a public is created only when the indirect consequences of actions are recognised and attempts at regulating them are being undertaken. Dewey defines the public as consisting "of all those who are affected by the indirect consequences of transactions to such an extent that it is deemed necessary to have those consequences systematically cared for" (1927, 15-16). This first distinction seems the most palpable, but is not consistently kept up. When indicating that public opinion can potentially be held by an individual, the lines between public and private are already blurred (Splichal 2000). As discussed before, this assumption is inherent in the argument that public opinion is the sum of individual opinions.

Herbst (1993) and Splichal (1999) agree that what is asked in opinion polls is not public opinion because the conditions of intentionality and public representation are not met. Opinion polls are anonymous: Although respondents are aware that their replies might be published (in an aggregate form), the actual answer is given in a private setting. The expression is eventually published, but made in anonymity, so the connection between the opinion holder and the expression is not public. Thus, opinion polls are not public, but not exclusively private either. Subsequently we will look for a term suited to describe this paradox.

Polling critics often claim that polling data is nothing but an artefact of the interplay between opinions, or rather attitudes, and survey instruments (Ginsberg 1986; Bourdieu 1972/1979; Herbst 1993; Blumer 1948; Splichal 1999). Osborne and Rose $(1999,382)$ take this a step further and write that only from the advent of polling on, public opinion actually existed: "public opinion is created by the procedures that are established to 'discover' it." Opinion polls in the least complex sense (excluding deliberative polling) might not touch on the public, and might not even refer to opinion. A solution to this dilemma of conceptual ambiguity can be found when considering the contradiction between the public, the crowd, and the mass.

On first thought, crowd and mass opinions could be summarised as popular opinion instead of public opinion. However, Cooley (1909/1920) points to another terminology that might be more appropriate than the term "opinion" when he speaks of sentiments as main contribution of masses to government. Tarde (1969), Cooley (1909/1920), Park (1972), and Le Bon (1897/1960) have established that crowds do not act rationally but are bound by a single unifying emotion. Any expression, act, or utterance originating from a crowd cannot be opinion. As the 
expression is emotional in any case, the term sentiment seems more appropriate. Moreover, as stated before, members of a mass are bound by common attention only, neither by emotion nor discussion. Cooley (1909/1920) explicates that the sentiment of the masses most commonly is a judgment of persons. This is demonstrated in elections, as it is known that a large proportion of the electorate votes according to their sympathies toward a candidate, not according to their preference for a specific policy (Childs 1965). The voting decision therefore is clearly dominated by affect. Considering that voting is often regarded as the ultimate expression of public opinion (Price 1992; Binkley 1928), this connection justifies the use of the term "sentiment."

It has been noted that opinion is necessarily connected to thought (Price 1992; Herbst 1993). Attitudes, on the other hand, are closely connected to emotion and require less or no cognitive effort. As demonstrated before, research efforts directed at masses aim more at attitudes and less at opinions. This is not to say that respondents in an opinion poll do not have opinions or are not members of any public. In the very instance of being asked, though, several aspects deny the opinion character of their replies. In addition to being asked in private as a private person, the questions posed by polling agencies are often unrelated to the respondent's own issue agenda (Ginsberg 1986). Therefore, the person may very well be a member of a public that holds a public opinion, but it is less likely that the opinion would be on the very question put forward. In such cases, the rationality induced by discussion - or at least consideration - is missing and the response is likely to refer to an attitude more than to an opinion.

Understanding the results of opinion polling as sentiment entirely conforms to the definition of opinion provided by polling advocate Allport (1937) who explicates that public opinion is the sum of individual expressions in favour of or against conditions, persons, or proposals that might affect action towards the object concerned. According to Price (1992), this definition is actually a definition of attitudes, as is Key's (1961) description of "mass opinion" as a tendency toward certain behaviour. Key justifies his definition of public opinion as agglomerate of individual expressions by stating that the mass has attitudes, too. Although Key discusses mass opinion as variation of public opinion, he implicitly provides the means of differentiation between the two. He uses the terms "public opinion" and "public attitude" seemingly synonymous and in doing so is supported by Childs (1939) who defines opinion as the verbal expression of an attitude, which again is a predisposition to act in a specific manner. Furthermore, public opinion polling "transformed public opinion from a behavioural to an attitudinal phenomenon" (Ginsberg 1986, 69) by not demanding any kind of action on behalf of the "opinion" holder and by having at its foundation the application of psychological measures of attitudes (Price 1992). This obvious shift from cognition to affect again justifies the use of the term sentiment.

The last terminological question refers to the nature of the sentiment. It has already been established that it is not public. However, it does not seem appropriate to apply the term "private." First, in the case of passive crowds, the demonstration of sentiment is certainly not private but happens in publicly accessible places. Second, with regard to Harrison's (1940) statement that only that is private that is said to someone known, a friend, family member, or acquaintance, responses given to an interviewer cannot be termed private. 
"Mass" and "popular" are the attributions most commonly used alongside "public." Additionally, Mills (1956) adopts "primary public" and "plebiscite." The term mass would be insufficient to account for Tönnies' public and published opinion as forms of social will that is expressed as sentiment but is neither private nor public. To differentiate between primary and secondary public would be intriguing insofar as the terminology would mirror Tönnies' duality of community (primary groups) and society (secondary groups). On the other hand, the misleading use of "public" would not entirely be taken care of.

Plebiscite stands for a direct vote of electorate but also, according to the Oxford English Dictionary, for a public expression of the wishes or opinion of a community. Both this and the denomination "popular" refer to the "common people" without added attributes (Price 1992), therefore both would be useful to describe the expression of mass and crowd sentiments. However, "plebiscite" has a strong political and democratic connotation that is not entirely congruent with the numerous apolitical facets that are potential objects of sentiment. Consequently, "popular sentiment" seems the most appropriate nomenclature.

Having introduced Tönnies' typology of public opinion and pointed toward other contemporary conceptualisations, the conclusion of this paper is a rough sketch of a framework based on Tönnies' theory and including further conceptualisations, most of them devised later than his own theory.

\section{Typology}

So far Tönnies' typology has been affirmed (for instance by the integration of active crowds and the crowd mind) as well as expanded. It was possible to account for empirical public opinion research and polling by including masses in the model, but conceptually discriminating them and passive crowds from what Tönnies defined as being public. Moreover, different perspectives have contributed new conceptual aspects of public and popular expressions.

The results of the discussion in this paper are summarised in table 5. Here, Tönnies' public opinion is appended by popular sentiment as an additional form of social will. In order to stringently apply Tönnies' conceptualisation, only ephemeral, fluid, and solid opinion of the public can be termed public in the true sense, whereas his public opinion, published opinion and mass sentiment are not public but popular. These six forms of social will have different subjects, different collectives that form the will. Moreover, different subjects employ different means of expressing themselves. It has also been made clear in the course of this paper that these different approaches to "public opinion" come from different research traditions or schools of thought which we have tried to allocate to the different conceptions. All these aspects have been discussed before and will be integrated subsequently.

We will use the example of masses to illustrate the line of reasoning leading up to our summary in table 5. We established that masses are not public and can therefore not form any public opinion - their will takes the form of popular sentiment (1) and they produce mass sentiment (2). The will of the masses is established by counting votes and determining what the majority wants, therefore the majority is the subject of the mass sentiment (3). The means of expression are votes in elections or opinion polls (4). According to the nature of votes, it is only possible for 
masses to express approval or disapproval (5). Obviously, the scientific approach to analyze the masses and determine their will is mostly quantitative empirical research, such as opinion polling. This represents one side of a continuum with the other side being normative theory that is concerned with ideal types, such as Tönnies' work. There are several more aspects that could be differentiated for these different forms of social will, for instance the sphere the subjects move and form their will in. Unfortunately, specifics about the public sphere have not been discussed sufficiently in this paper to include them in the typology.

Published opinion and public opinion are two more forms of popular sentiment. The former has no apparent subject, according to our line of argument the latter has its subject in what Tarde (1969) calls passive crowds. Both express themselves in public as opposed to private or intimate (cf. Tönnies 1922), but expressions from different groups or individuals are not connected, there is no public debate, only isolated utterances. As is the case with masses, both can only express approval or disapproval, no refined expression is possible as there is no deliberation leading to the sentiment.

Deliberation is part of the process of forming opinion of the public, in all three aggregate states. As pointed out earlier, the main difference between them is the degree of unity among the members of the public in terms of a specific opinion. Another difference is in their subject: Solid opinion of the public as normative ideal corresponds to the elitist concept of an imaginary group of educated or at least interested people. As fluid opinion changes with Zeitgeist, so does its subject, there is not one consistent concept of a specific group as source of fluid opinion of the public. The same goes for gaseous opinion, and as we established earlier, these groups can be termed, with Tarde (1969), active crowds. The main characteristic of all normative public opinion, though, is its formation through public debate and its expression in deliberation, in the analysis of a problem and the process of finding consensus in terms of a solution.

Table 5 is an attempt at integrating the arguments made in this paper into a typology starting with and building upon Tönnies' theory of public opinion. Obviously, this classification has to be understood as representing ideal types that might overlap empirically.

Table 5: Typology of Conceptualisations for the Study of Public Opinion and Popular Sentiments

\begin{tabular}{|l|l|l|l|l|l|l|}
\hline Dimensions & \multicolumn{5}{|c|}{ Forms of social will } \\
\hline (1) Phenomenon: & \multicolumn{3}{|c|}{ Popular sentiment } & \multicolumn{3}{c|}{ Opinion of the public } \\
\hline (2) Product: & $\begin{array}{l}\text { Mass } \\
\text { sentiment }\end{array}$ & $\begin{array}{l}\text { Published } \\
\text { opinion }\end{array}$ & $\begin{array}{l}\text { Public } \\
\text { opinion }\end{array}$ & Ephemeral & Fluid & Solid \\
\hline $\begin{array}{c}\text { (3) Subject: } \\
\text { majority }\end{array}$ & $\begin{array}{l}\text { none } \\
\text { apparent }\end{array}$ & $\begin{array}{l}\text { passive } \\
\text { crowds }\end{array}$ & $\begin{array}{l}\text { active } \\
\text { crowds }\end{array}$ & $\begin{array}{l}\text { inconsistent } \\
\text { groups }\end{array}$ & $\begin{array}{l}\text { imaginary } \\
\text { group }\end{array}$ \\
\hline $\begin{array}{c}\text { (5) Means of } \\
\text { expression: }\end{array}$ & vote, polls & $\begin{array}{l}\text { public } \\
\text { utterance }\end{array}$ & $\begin{array}{l}\text { public } \\
\text { utterance }\end{array}$ & $\begin{array}{l}\text { public } \\
\text { debate }\end{array}$ & $\begin{array}{l}\text { public } \\
\text { debate }\end{array}$ & $\begin{array}{l}\text { public } \\
\text { debate }\end{array}$ \\
\hline
\end{tabular}




\section{Conclusion}

Tönnies' conceptualisation of public opinion has not had much influence in the field of public opinion study. Splichal $(1999,101-102)$ blames this neglect on political circumstances in Nazi Germany, which Tönnies opposed, and his theories' consequent disappearance from the academic stage, which, in terms of public opinion, was soon dominated by US-American scholars. Until today, Tönnies remains a blind spot. This is regrettable most of all because Kritik der öffentlichen Meinung "remains one of the most coherent analyses of public opinion" (Splichal 1999, 101), but also because contemporary public opinion research could benefit vastly from his fundamental theoretical systematisation.

In this paper we have attempted to show that the theoretical foundation provided by Tönnies is adequate to serve as framework for the general study of public and popular expressions. Such a framework, as sketched crudely in the previous paragraph, could be useful to integrate the field and improve consistency as well as efficiency of research on opinion and sentiment. Both public opinion and popular sentiment have their place in democracy, and certainly in the social and political realities of everyday life. Therefore there can be no argument against declaring the exact position of research by clearly naming its object - popular sentiment is no less important than public opinion.

This paper was a first step in building a conceptual model of the study of public opinion and popular sentiments. Accordingly, many significant theories have been excluded. Conceptual aspects other than public opinion and the public have also been referred to only fleetingly. Nevertheless, it should have become apparent that it is possible to organise the conceptual chaos in the field by making use of the theories that are out there.

\section{Acknowledgements}

The author wishes to thank Slavko Splichal for his valuable comments on Tönnies' work and on this manuscript.

\section{Notes:}

1. Splichal and Hardt $(2000,56)$ suggest the terms "organic" or "natural" will instead of essential will, and "reflexive" or "rational" will instead of arbitrary will. This terminology emphasises the role of rationality in the latter, which is neither apparent in the original German term Kürwille nor in the translation as "arbitrary will" as provided by Cahnmann and Heberle (Tönnies 1971). The literal meaning of Kürwille, and also of the term Willkür as used by Tönnies in the first two original editions of Gemeinschaft und Gesellschaft, does indeed refer to arbitrariness. We would suggest, though, as seems to be implied by Splichal and Hardt, that Tönnies' original terminology is not necessarily precise in view of the actual meaning of the concept. Both for the German and the English term the most obvious connotations are "baseless" and "random," whereas Tönnies clearly refers to rationally founded will when he defines Kürwille as a "product of thinking itself, which therefore can only be true in relation to its originator, the subject of thought" (Tönnies 1887/1912, 104; own translation). Furthermore, the opposition between organic and rational more clearly reveals the dichotomy between psychological and rational, which Tönnies obviously intended. This is again clarified in the German original where he describes Wesenswille as "psychological equivalent of the human body, or the principle of the unity of life" (p. 103; own translation).

2. This is only one instance that illustrates the conceptual ambiguity in the study of public opinion. In this case the author provides a definition of public opinion that does not match his own, but other authors' definitions of the public. Somewhat similarly, Tönnies (1922) matches his understanding of the public with his idea of "opinion of the public" - but there is no specific description of the public 
according to "public opinion," only the indication that public opinion has no apparent subject. Tarde helps filling this gap.

3. The use of the term "opinion" will be discussed later in this paper.

\section{References:}

Allport, Floyd H. 1937. Toward a Science of Public Opinion. Public Opinion Quarterly 1, 7-23.

Beniger, James R. 1987. Toward an Old New Paradigm: The Half-Century Flirtation With Mass Society. The Public Opinion Quarterly 51, 4, S46-S66.

Binkley, Robert C. 1928. The Concept of Public Opinion in the Social Sciences. Social Forces 6, 389396.

Blumer, Herbert. 1966/2000. The Concept of Mass Society. In M. S. Lyman and J. A. Vidich (eds.), Selected Works of Herbert Blumer: A Public Philosophy for Mass Society, 337-352. Urbana, IL: University of Illinois Press.

Blumer, Herbert. 1948. Public Opinion and Public Opinion Polling; With Discussion. American Sociological Review 13, 542-554.

Blumer, Herbert. 1946. Collective Behavior. In A. M. Lee (ed.), New Outlines of The Principles of Sociology, 167-222. New York, NY: Barnes and Noble.

Borch, Christian. 2005. Urban Imitations: Tarde's Sociology Revisited. Theory, Culture \& Society 22(3), 81-100.

Bourdieu, Pierre. 1972/1979. Public Opinion Does Not Exist. In A. Mattelart and S. Siegelaub (eds.), Communication and Class Struggle, 124-130. New York, NY: International General.

Childs, Harwood L. 1965. Public Opinion, Nature, Formation and Role. Princeton, NJ: Van Nostrand.

Childs, Harwood L. 1939. "By Public Opinion I Mean". Public Opinion Quarterly 3, 327-336.

Cooley, Charles H. 1909/1927. Social Organization: A Study of the Larger Mind. New York, NY: C. Scribner's Sons.

Dewey, John. 1927. The Public and its Problems. New York: H. Holt and Company.

Fishkin, James S., Robert C. Luskin and Roger Jowell. 2000. Deliberative Polling and Public Consultation. Parliamentary Affairs 53, 4, 657-666.

Ginsberg, Benjamin. 1986. The Captive Public: How Mass Opinion Promotes State Power. New York, NY: Basic Books.

Gollin, Gillian L. and Albert E. Gollin. 1973. Tönnies on Public Opinion. In W. J. Cahnman (ed.), Ferdinand Tönnies: A New Evaluation, 181-203. Leiden: Brill.

Graves, W. Brooke. 1939. American Public Opinion as Bryce Described it, and as it is Today. In R. C. Brooks (ed.), Bryce's American Commonwealth: Fiftieth Anniversary, 80-112. New York, NY: Macmillan.

Habermas, Jürgen. 1992. Further Reflections on the Public Sphere. In C. Calhoun (ed.), Habermas and the Public Sphere, 421-461. Cambridge, MA: MIT Press.

Habermas, Jürgen. 1962/1991. The Structural Transformation of the Public Sphere: An Inquiry Into a Category of Bourgeois Society. Cambridge, MA: MIT Press.

Harrison, Tom. 1940. What is Public Opinion? The Political Quarterly 11, 368-383.

Herbst, Susan. 1993. Numbered Voices: How Opinion Polling Has Shaped American Politics. Chicago, IL: University of Chicago Press.

Kant, Immanuel. 1795/1939. Perpetual Peace. New York, NY: Columbia University Press.

Keane, John. 1982. Elements of a Radical Theory of Public Life: From Tönnies to Habermas and Beyond. Canadian Journal of Political and Social Theory 6, 3, 11-49.

Key, Valdimer O. 1961. Public Opinion and American Democracy. New York, NY: Knopf.

Le Bon, Gustave. 1897/1960. The Crowd: A Study of the Popular Mind. New York, NY: Viking Press.

Mills, C. Wright. 1956. The Power Elite. London: Oxford University Press.

Newcomb, Theodore M. 1948. Discussion. American Sociological Review 13, 549-552.

Noelle-Neumann, Elisabeth. 1976. Öffentlichkeit als Bedrohung: Beiträge zur empirischen Kommunikationsforschung. Freiburg: Karl Alber.

Osborne, Thomas and Nikolas Rose. 1999. Do the Social Sciences Create Phenomena? The Example 
of Public Opinion Research. The British Journal of Sociology 50, 3, 367-396.

Palmer, Paul A. 1938. Ferdinand Tönnies'Theory of Public Opinion. Public Opinion Quarterly 2, 584595.

Park, Robert E. 1972. The Crowd and the Public, and Other Essays. Chicago, IL: University of Chicago Press.

Price, Vincent. Forthcoming. Public Opinion and Democratic Theory. In W. Donsbach and M. W. Traugott (eds.), International Handbook of Public Opinion Research. Thousand Oaks, CA: Sage Publications.

Price, Vincent. 1992. Public Opinion. Newbury Park, CA: Sage Publications.

Splichal, Slavko and Hanno Hardt. 2000. Tönnies, Public Opinion, and the Public Sphere. In H. Hardt and S. Splichal (eds.), Ferdinand Tönnies on Public Opinion, 49-110. Lanham, MD: Rowman \& Littlefield.

Splichal, Slavko. 2000. Defining Public Opinion in History. In H. Hardt and S. Splichal (eds.), Ferdinand Tönnies on Public Opinion, 11-48. Lanham, MD: Rowman \& Littlefield.

Splichal, Slavko. 1999. Public Opinion: Developments and Controversies in the Twentieth Century. Lanham, MD: Rowman \& Littlefield.

Tarde, Gabriel. 1969. On Communication and Social Influence: Selected Papers. Chicago, IL: University of Chicago Press.

Thompson, John B. 1995. The Media and Modernity: A Social Theory of the Media. Stanford, CA: Stanford University Press.

Tönnies, Ferdinand. 1971. In W. J. Cahnmann and R. Heberle (eds.), Ferdinand Tönnies on Sociology: Pure, Applied, and Empirical. Selected Writings. Chicago, IL: University of Chicago Press.

Tönnies, Ferdinand. 1922. Kritik der öffentlichen Meinung. Berlin: J. Springer.

Tönnies, Ferdinand. 1887/1912. Gemeinschaft und Gesellschaft: Grundbegriffe der reinen Soziologie. Berlin: K. Curtius. 


\section{When talk is a science...}
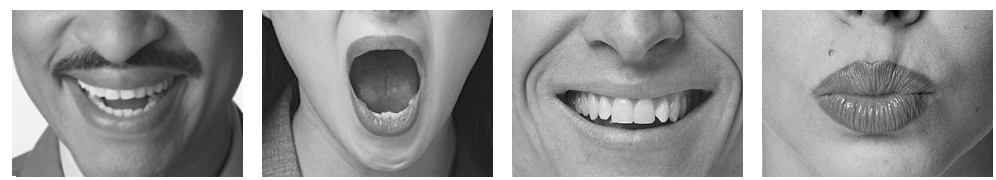

\section{Linguistics \& Language Behavior Abstracts}

Comprehensive, cost-effective, timely coverage of current ideas in linguistics and language research

Abstracts of articles, books, and conference papers from more than 1,100 journals plus citations of relevant dissertations as well as books and other media.

Available in print or electronically through CSA Illumina (www.csa.com).

Contact sales@csa.com for trial Internet access or a sample issue.

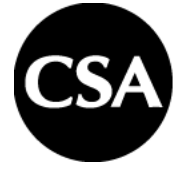

